\title{
Incidence of Palmaris Longus Muscle Absence in Nigerian Population
}

\author{
Incidencia de la Ausencia del Músculo Palmar Largo en la Población de Nigeria
}

"Oluyemi Kayode A.; "Adesanya Olamide A.; ** Odion Blessing I. \& *** Ukwenya Victor O.

\begin{abstract}
KAYODE, A. O.; OLAMIDE, A. A. BLESSING, I. O. \& VICTOR, O. U. Incidence of palmaris longus muscle absence in Nigerian population. Int. J. Morphol., 26(2):305-308, 2008.

SUMMARY: A lot has been reported about variation of palmaris longus muscle in journals and conventional textbooks. The incidence of palmaris longus muscle absence among people of the six geo-political zones of Nigeria was evaluated using 600 subjects. $31.25 \%$ (187 subjects) lack palmaris longus muscleon either of the forearms. $12.5 \%$ ( 75 subjects) shows unilateral absence and $18.75 \%$ (112 subjects) shows bilateral absence. $25 \%$ (150) of subjects lacks palmaris longus muscleon their right forearms while $25 \%$ also lacks it on their left forearms. $6 \%$ (37) shows double tendons of palmaris longus muscleon both forearms. Highest incidence of absence was recorded among people of South-West zone.
\end{abstract}

KEY WORDS: Palmaris longus muscle; Tendons; Flexors muscles; Forearm.

\section{INTRODUCTION}

Much has been reported about the variations in palmaris longus muscle in relation to its morphology, origin, insertion, nerve supply and presence or absence in different individuals. Proximally, it is attached to the medial epicondyle of the humerus along with other superficial flexors of the forearm. Distally its long thin tendon forms the superficial portion of the mid palmar fascia (Nigro, 2001). Skin and fascia of the palm and digital webs give attachment to the fibres of palmar fascia. The palmaris longus muscle is innervated by a branch of the median nerve (Linell, 1921; Sunderland \& Ray, 1946).

Palmaris longus muscle is one of the superficial slender muscles of the forearm that act on the skin and distal digital webs. It has been described as a phylogenetically degenerate metacarpophalangeal joint flexor (Gray et al., 1999; Jones, 1941). Palmaris longus muscle is a choice muscle in cosmetic, plastic and reconstructive surgery. It serves as an anchor for the skin and fascia of the hand, resisting horizontal shearing forces in a distal direction, which would tend to deglove the skin of the palm. Often absent on one or both sides, the muscle is very variable. (Machado \& Didio 1967; Stack, 1973).
The first three-headed reversed palmaris longus muscle was recorded by Yildiz et al. (2000) in a 36 year old woman. Oommen (2002) has also recorded inverse (updown) palmaris longus muscle in a cadaver, in which the muscle originates by a long thin tendon from the medial epicondyle by the common flexor tendon and from the antebrachial fascia in both limbs. He recorded that the muscle stemmed from a long tendon instead of muscle belly. On both sides the tendon was replaced by a muscle belly around the middle of the fore-arm. In the region of the wrist the muscle fibers ended and a tendon continued into the palmar aponeurosis. An atypical innervation was recorded in cadaver at New Delhi, India (Chauhan, 2003). Palmaris longus muscle is present in about 70-85\% population (Wehbé, 1992) and fully developed at birth (Vastamäki, 1987).

Nigeria, a Western Africa nation, bordering the North Atlantic Ocean, between Benin and Cameroun, is the largest black nation in the world. It is located on area 92376868sq kilometers, land area of 910770 sq kilometers. The population is estimated at 130.000000 with more than 250 ethnic groups. The 31 states are grouped into 6 geo-political

* Department of Anatomy, School of Basic Medical Sciences, Igbinedion University, Okada. P.M.B 0006, Benin City, Edo State, Nigeria.

** Department of Medicine, School of Basic Medical Sciences, University of Benin, P.M.B, Benin City, Edo State, Nigeria.

**** Department of Anatomy, School of Basic Medical Sciences, University of Lagos College of Medicine, Akoka, Lagos. 
zones as follows: North-Central (Benue, Kogi, Kwara, Nasarawa, Niger, Plateau, and Federal Capital Territory, Abuja), North-Eastern (Adamawa, Bauchi, Borno, Gombe, Taraba and Yobe), North-Western (Jigawa, Kaduna, Kano, Katsina, Kebbi, Sokoto and Zamfara), South-Eastern (Abia, Anambra, Ebonyi, Enugu, and Imo) South-South (Akwa Ibom, Bayelsa, Cross River, Delta, Edo and Rivers) and South-Western (Ekiti, Lagos, Ogun, Ondo, Osun and Oyo).

Most of the recorded variations occur among the Caucasians and Chinese. Only few as been reported concerning the percentage incidence of palmaris longus muscle among Nigerian.

This study aims at evaluating the incidence of palmaris longus muscle absence among Nigerian population, using the three major ethnic groups as case studies.

\section{MATERIAL AND METHOD}

In 600 subjects ( 300 males \& 300 females) were randomly sampled without replacement, according to Spiegel \& Stephens (1998), from the staff and student populations of Igbinedion University, Okada, Edo State, and University of Benin, Benin City, Edo State. They represented the six geopolitical regions of Nigeria: SouthSouth (100), South-West (100), South-East (100), NorthNorth (100), North-East (100) and North-Central (100). The subjects' ages range between 19 years and 35 years.

They were made to perform various exercises to test for the absence of palmaris longus muscle in both forearms. The tests were combined according to Sebastin \& Lim (2006). The tests are as follows:

Standard test (Schaeffer's test): The subject is asked to oppose the thumb to the little finger and then flex the wrist.

Thompson's test: The subject is asked to make a fist, then flex the wrist and finally the thumb is opposed and flexed over the fingers.

Mishra's test I: The metacarpo-phalangeal joints of all fingers are passively hyperextended by the examiner and the subject is asked to actively flex the wrist.

Mishra's test II: The subject is asked to abduct the thumb against resistance with the wrist in slight palmar flexion.
Pushpakumar's "two-finger sign" method: The subject is asked to fully extend the index and middle finger, the wrist and other fingers are flexed and finally the thumb is fully opposed and flexed.

\section{RESULTS}

Among the 60 subjects examined in this work, $31.25 \%$ (187 subjects) lack palmaris longus muscle on either of the forearms. $12.5 \%$ (75 subjects) shows unilateral absence and $18.75 \%$ (112 subjects) shows bilateral absence.

\section{DISCUSSION}

The morphology, nerve supply and functions of palmaris longus muscle have been extensively discussed by Chauhan. Some authors suggest that apart from its ethnic variations, its absence is more common in women, bilateral absence is more common, and that unilateral absence occurs more frequently on the left side (Schaeffer, 1909) Others have attempted to correlate the absence of the palmaris longus muscle with other anatomical anomalies, like an anomalous superficial palmar arch, an absence of the plantaris, etc. (O'Sullivan \& Mitchell, 2002; Ito et al., 2001). None of the subjects used in this study has any record of phenotypical anomalies.

Among the 600 subjects examined in this work, $31.25 \%$ (187 subjects) lack palmaris longus muscle on either of the forearms. This is in consonance with the work of Wehbé, who reported $70-85 \%$ presence of palmaris longus muscle. $12.5 \%$ (75 subjects) shows unilateral absence and $18.75 \%$ (112 subjects) shows bilateral absence. These confirmed the higher percentage recorded for bilateral against unilateral incidence by Schaeffer and Reimann et al. (1944). 25\% (150) of subjects lacks palmaris longus muscle on their right forearms, while $25 \%$ also lacks it on their left forearms. This suggests that absence of palmaris longus muscle is equally encountered against the account of Schaeffer and Reimann et al., who reported that it is more absent on the left forearm than the right forearm. Also in this study, 6\% (37) shows double tendons of palmaris longus muscle on both forearms. The muscle may have a proximal tendon or be reduced to a tendinous strand. It may be digastric or reduplicated. It may also end in antebrachial fascia, tendon of flexor carpi ulnaris muscle, pisiform, scaphoid, etc. (Williams et al., 1995 and Oommen). 
Highest incidence of absence was recorded among people of South-West zone. The reason for the highest incidence among the people of South-West zone is not known. It appears that the gene responsible for the development of palmaris longus muscle is less dominant among this zone. palmaris longus muscle is completely developed at birth (Vastamäki).

KAYODE, A. O.; OLAMIDE, A. A. BLESSING, I. O. \& VICTOR, O. U. Incidencia de la ausencia del músculo palmar largo en la población de Nigeria. Int. J. Morphol., 26(2):305-308, 2008.

RESUMEN: Mucho se ha informado acerca de la variación del músculo palmar largo en revistas y libros de texto convencionales. La incidencia de ausencia del músculo palmar largo entre las personas de los seis zonas geo-políticas de Nigeria se evaluó usando 600 sujetos. 31,25\% (187 sujetos) no tenían músculo palmar largo en cualquiera de los antebrazos, 12,5\% (75 sujetos) mostró ausencia unilateral y 18,75\% (112 sujetos) mostró ausencia bilateral. 25\% (150) de los sujetos carece de músculo palmar largo en su antebrazo derecho, mientras que el 25\% carece de él también en su antebrazo izquierdo. $6 \%$ (37) muestra dobles tendones de músculo palmar largo en ambos antebrazos. Mayor incidencia de ausencia se registró entre las personas de la zona Sur-Oeste.

PALABRAS CLAVE: Palmar largo; Tendón, Músculos flexores, antebrazo.

\section{REFERENCES}

Chauhan, R. Atypical innervation of palmaris longus - A case report. J. Anat. Soc. India, 52(2):171-3, 2003.

Gray, H.; Bennister, L. H.; Berry, M. M. \& Williams, P. L. Gray's Anatomy: The Anatomical Basis of Medicine and Surgery. $38^{\text {th }}$ ed. London, Churchill Livingstone, 1999. p. 853 .

Ito, M. M.; Aiko, M.; Kida, M. Y.; Ishii, S.; Kumaki, K. \& Tanaka, S. Length and width of the tendinous portion of the palmaris longus: a cadaver study of adult Japanese. J. Hand Surg. (Am)., 26(4):706-10, 2001.

Jones, F. W. The principles of anatomy as seen in the hand. Baillere. London, Tindall and Cox, 1941.

Linell, E. The distribution of the nerves in the upper limb, with reference to variabilities and their clinical significance. J. Anat., 55(2-3):79-112, 1921.

Machado, A. B. \& Didio, L. J. Frequency of the musculus palmaris longus studied in vivo in some Amazon indians. Am. J. Phys. Anthropol., 27(1):11-20, 1967.

Nigro, R. O. Anatomy of the flexor retinaculum of the wrist and the flexor carpi radialis tunnel. Hand Clin., 17(1):614, 2001.

Oommen, R. A. Palmaris longus - Upside Down. J. Anat. Soc. India, 51(2):232-3, 2002.

O'Sullivan, E. \& Mitchell, B. S. Association of the absence of the palmaris longus tendon with an anomalous super- ficial palmar arch in the human hand. J. Anat., 201(5):405-8, 2002.

Reimann, A. F.; Daseler, E. H.; Anson, B. J. \& Beaton, L. E. The palmaris longus muscle and tendon; a study of 1600 extremities. Anat. Rec., 89:495-505, 1944.

Schaeffer, J. P. On the variations of the palmaris longus muscle. Anat. Rec., 3:275-8, 1909.

Sebastin, S. J. \& Lim, A. Y. Clinical assessment of absence of the palmaris longus and its association with other anatomical anomalies-- a Chinese population study. Ann. Acad. Med. Singapore, 35(4):249-53, 2006.

Spiegel, M. R. \& Stephens, L. J. Schaum's outline of theory and problems of statistics, $3^{\text {rd }}$ ed. New York, McGrawHill, 1998.

Stack, H. G. The palmar fascia. Edinburgh, Churchill Livingstone, 1973.

Sunderland, S. \& Ray, L. Metrical and non metrical features of the muscular rameaux of the median nerves. J. Comp. Neurol., 85:191-203, 1946.

Vastamäki, M. Median nerve as free tendon graft. J. Hand Surg. (Br)., 12(2):187-8, 1987.

Wehbé, M. A. Tendon graft donor sites. J. Hand Surg. (Am)., 17(6):1130-2, 1992.

Williams, P. L; Bannister, L. H; Dyson, M; Berry, M.M; 
KAYODE, A. O.; OLAMIDE, A. A. BLESSING, I. O. \& VICTOR, O. U. Incidence of palmaris longus muscle absence in Nigerian population. Int. J. Morphol., 26(2):305-308, 2008.

Collins, P.; Dussek, J. E. \& Fergusson, M. W. J. Gray's Anatomy In: The muscular system. $38^{\text {th }}$ Ed. London, Churchill Livingstone, 1995. p. 846.

Yildiz, M.; Sener, M. \& Aynaci, O. Three-headed reversed palmaris longus muscle: a case report and review of the literature. Surg. Radiol. Anat., 22(3-4):217-9, 2000.
Correspondence to:

Oluyemi Kayode A.

Department of Anatomy

School of Basic Medical Sciences.

Igbinedion University, Okada.

P.M.B 0006

Benin City, Edo State

NIGERIA

Phone: +234-805-986-0788

Email: kayodedanatomist@yahoo.com

Received: 08-10-2007

Accepted: 21-01-2008 